Канаш О. Є., аспірант

Національний університет

імені адмірала Макарова

м. Миколаїв, Украӥна

DOI: https://doi.org/10.30525/978-9934-26-068-1-5

\title{
ДУАЛЬНА ВИЩА ОСВІТА ЯК ВІДПОВІДЬ НА ЕКОНОМІЧНИЙ ЗАПИТ СУСПІЛЬСТВА
}

Дедалі гучніше в Україні лунають пропозиції активно запроваджувати дуальні технології не лише в закладах професійно-технічної освіти, але й в університетах. Про це, зокрема, йдеться в Концепції підготовки фахівців за дуальною формою здобуття освіти в Україні, яку Кабінет Міністрів затвердив своїм розпорядженням [1] та в плані заходів щодо іiі реалізації [2]. Як годиться, на виконання прийнятих рішень з гори до адміністрацій спеціально відібраних ЗВО посипалися розпорядження та вказівки: укласти договори з підприємствами, підписати тристоронні угоди та трудові контракти, забезпечити контроль, здійснювати моніторинг - традиційна бюрократична круговерть.

Маємо відзначити, що тема не залишається поза увагою шановних колег-науковців, студії яких висвітлюють цілу низку актуальних питань вже на прикладному рівні. Однак, більшість 3 них стосується освіти професійної [3; 4; 5]. I це виглядає природним 3 огляду на дефіцит робочих кадрів на більшості підприємств: від хлібопекарних до суднобудівних. Разом з тим, помилково було б абстрагуватись від важливих завдань які постають перед «білими комірцями». Особливо в контекстах процесів цифровізації виробничих технологій та широкого застосування інформаційно-комунікаційних інструментів, які в сукупності та взаємозв'язку отримали промовисту назву: четверта промислова революція. Від так, роль закладів вищої освіти виглядає як ніколи важливою. Але звести ідею дуальності 
щодо них виключно до «заходів» та «звітів про їх виконання» означає іï елементарну дискредитацію.

На наше переконання, організація дуальної університетської освіти - справа напрочуд складна і розраховувати на те, що іiі буде розв'язано виключно адміністративними методами, означає перебувати у небезпечній омані. Ключовою складовою руху до омріяної мети $є$ створення умов, які б мотивували саме отримувачів освітніх послуг знаходити в дуальності сенс свого життя. Спочатку впродовж періоду фахового становлення i надалі - підтримання на належному рівні важливих професійних компетенцій. Щодо університетів, то прикро, якщо вони обійдуть стороною питання оптимізації змісту освіти в координатах дуальності, а промисловість залишиться на старому технологічному рівні. Не про таку дуальність мріється.

Виходячи 3 вищевикладеного, постала мета зануритися у природне середовище системи дуальної вищої освіти й в такий спосіб з'ясувати особливості роботи відповідного механізму, споглядаючи його 3 середини. У якості прикладу обрано Німеччину, оскільки, по-перше, вона є іï родоначальницею, та, по-друге, довела дуальну освіту до взірцевої досконалості. До того ж, методики, розроблені німецькими фахівцями, прихильно сприймаються країнами, розташованими на усіх континентах планети.

Виявилося, що поштовхом до поширення дуалістичної концепції за межі професійно-технічної освіти стало перетворення наприкінці XX-го сторіччя університетського сегмента ринку освітніх послуг у масовий. Він позбувся статусу «зони для привілейованих суб'єктів»- переважна більшість випускників шкіл рушили до вишів. Відбулося й переналаштування вподобань молодих кваліфікованих працівників, які замість роботи за спеціальністю, що вони набули в професійно-технічних училищах, виявляли бажання продовжувати навчання 3 метою отримати визнаний міжнародною академічною спільнотою ступінь бакалавра, а то і магістра. Спрацював у чистому вигляді «стадний інстинкт». 
Для того, щоб бізнес та держава не втратили кадри й гроші, витрачені на їхню підготовку, почалися інтенсивні консультації 3 академічною спільнотою. Врешті консенсус було знайдено і до справи залучилися [6, с. 8]:

1. Дуальні коледжі (на них припадає шість відсотків програм вищої дуальної освіти).

2. Університети (сім відсотків) слугують для підтримки та розвитку науки шляхом проведення дослідницької та академічної діяльності. Вони пропонують широкий спектр професій за програмами, що відповідають п'ятому та шостому рівням Міжнародної стандартної класифікації освіти (ISCED) [7]. Наділений виключним привілеєм пропонувати програми науковоосвітнього рівня магістра та доктор філософії.

3. Професійні академії (23\%). В деяких федеральних землях ФРН (спочатку в Баден-Вюртемберг, Тюрингія, РейнландПфальц, Саксонія, а тепер, після успішного завершення пілотного проєкту, - в усіх без виключення) вони були об'єднані в Кооперативні держані дуальні університети (КДДУ).

4. Університети прикладних наук (абсолютні лідери $364 \%$ освітніх програм)-орієнтовані на практику ЗВО, освітньопрофесійні програми яких передбачають стажування та семестрові практики на підприємствах. У перспективи отримати ступені бакалавра та магістра.

5. Університети дистанційного навчання. У Федеративній республіці їх більше як 160.

Дуальний курс навчання, принаймні в Німеччині, пропонується в декількох формах: інтегрований курс учнівства (an integrating apprenticeship, інтегрований курс 3 досвідом роботи (integrating work experience), курс подвійного навчання (integrating professional employment) та курс безперервної практичної освіти (in-service).

Зауважимо, що також ми стикнулися 3 деякими об'єктивними проблемами. 3'ясувалося, зокрема, що в відповідній царині не існує в принципі стандартизованої термінології, оскільки уряди кожного регіону (землі) створюють власні правила і варіанти 
навчання. До імпровізацій влади на тему дуальності додають різноманіття й університети, користуючись своїми надзвичайно широкими академічними свободами.

Який 3 наведених варіантів не було б обрано здобувачем освітньої послуги, обов'язкова умова - укладання двох договорів: між освітньою установою та підприємством, а також між підприємством та студентом. Останній містить в собі, крім іншого, відомості про фінансову винагороду від роботодавця, а також зобов'язання студента відпрацювати на свого інвестора впродовж узгодженого проміжку часу.

Отже, переконуємося, що дуальна освіта, щонайменше окремі ii складові, вже знайома вітчизняним ЗВО і постає завдання наповнювати навчальні процеси новим змістом, застосовувати інноваційні інформаційні технології, що посилять ії ефективність 3 користю для стейкхолдерів. 3 цього випливає самостійне наукове завдання опрацювання інноваційні моделі імплементації дуальності вищої освіти в закладах вищої освіти нашої країни.

Опрацьовуючи їх, виходимо з усвідомлення, що дуальна вища освіта (при іiі розумному використанні) - ефективний інструмент розв'язання надзвичайно важливих задач, які постають перед урядами держав, органами місцевого самоврядування, бізнесом. Але тільки за умов, якщо:

- перші та другі дійсно опікуються розквітом країн (регіонів) через піднесення інтелектуальних, цифрових бізнесів та зростанням добробуту мешканців;

- інвестори, відчувають позитивні впливи комфортного інвестиційного середовища і вкладають кошти в підприємницькі проекти, що потребують фахових компетенцій відповідного гатунку, і готові 3 цього приводу співпрацювати 3 університетами;

- представники нових генерацій громадян пов'язують своє майбутнє 3 батьківщиною, де вони народилися, потребують працевлаштування на підприємствах, що здатні сприяти їх самореалізації за обраною спеціальністю. 


\section{Література:}

1. Концепція підготовки фахівців за дуальною формою здобуття освіти. Розпорядження Кабінету Міністрів України від 19 вересня 2018 р. № 660-р. URL: https://ips.ligazakon.net/document/KR180660?an=14.

2. План заходів 3 реалізації Концепції підготовки фахівців за дуальною формою здобуття освіти. Кабінет міністрів України. Розпорядження від 3 квітня 2019 року. №214-p. Київ. URL: https://zakon.rada.gov.ua/laws/show/214-2019$\% \mathrm{D} 1 \% 80 \#$ Text.

3. Ажажа М.А. Управління процесом упровадження дуальної освіти в професійну підготовку майбутніх фахівців. Публічне управління та митне адміністрування. 2019. № 1 (20). С. 14-24.

4. Дергунова М.Г. Дуальна модель вищої професійної освіти дорослих. [Dual model of higher professional education of adults]. Освіта дорослих: теорія, досвід, перспективи. 2014. Вип. 2. С. 137-145. URL: http://nbuv.gov.ua/UJRN/ OD_2014_2_19.

5. Новіков В.М. Практико-орієнтована модель професійної освіти. Демографія та соиіальна політика. 2019. № 2 (36). С. 152-164.

6. Duales Studium 2018 Statistiken \& Trends. Wegweiser-Duales-Studium. Köln, 2019, 17 p. URL: https://www.wegweiser-duales-studium.de/fileadmin/user_ upload/Inhalte/wegweiser-duales-studium.de/infos/E-Book-Duales-Studium-2018.pdf.

7. International Standard Classification of Education (ISCED). UNESCO Institute of Statistics. 2021. URL: http://uis.unesco.org/en/topic/internationalstandard-classification-education-isced. 